\title{
上肢障害者用食事支援ロボットの開発 \\ Development of Meal-Assistance Robot for People with Disabilities of Upper Limbs
}

\author{
田中 幹也(正会員), 西村 悠樹(非会員)
}

Kanya TANAKA and Yuki NISHIMURA

\begin{abstract}
Meal-assistance robots are required for people with disabilities of upper limbs because they need help with eating. However, they can not use some famous robots because they can not handle the robots using joysticks or touch sensors. Some people, who have pacemakers in the body, can also not use the robots because electromagnetic motors are included. We therefore develop a meal-assistance robot using ultrasonic motors and eye-interfaces. The features of our robot are as follows: our robot has electromagnetic compatibility because we use the ultrasonic motors, which are driven by frictional forces. Our robot is handled by using acts of user's eyes. Moreover, our robot does not vibrate so much because the arms of our robot move independently of each other. In this paper, we show the detail of our robot.
\end{abstract}

Key Words

Meal-assistance robot, disabilities of upper limbs, ultrasonic motor, eye-interface

\section{1.はじめに}

現在の日本では高齢化に伴い身体障害者の総数が増加傾向 にあり,そのうち, 食事の介護を必要とする上肢障害者は約 86 万人である. 1)食事の介護には多くの時間を要するため介護者 にとって大きな負担であり,また, 少子化に伴い相対的な介護者 の数は減少していく見込みである. 一方, 上肢障害者にとっても 好きなように食事を楽しみたいという思いは強く, 生活の質 (QOL: quality of life)の向上が求められている. このような現状 から，自立的に食事を行うための食事支援ロボットは介護現場に おいて強く必要とされている. 従来提案されている食事支援が可 能なロボットには iARM, ${ }^{2}$ HANDY1, 3)マイスプーン 4 )などがあ る.これらはいずれも, 電磁力モータで駆動し, ジョイスティックや タッチセンサで操作し, ロボットアームで掴むかスプーンで掬うこ とで食事支援を行うシステムである.これらのロボットを満足に使 用寸る為には, ペースメーカを装着していないことや腕・手・指な どの上肢に残存機能があることなどが求められる. また, アーム

2010 年 3 月 20 日受理

* 山口大学大学院理工学研究科

干755-0097 山口県宇部市常盤台 2-16-1

情報・デザイン工学系学域,

Graduate School of Science and Engineering, Yamaguchi

University, 2-16-1, Tokiwadai, Ube 755-0097, Japan
で上手に掴めないような食品やスプーンで容易に掬えないような 食物をロボッ卜操作で食べることは諦めざるを得ない. そこで著者 らは, 超音波モータ(USM: Ultrasonic Motor)で駆動し, 直交 座標系で動作し, 眼球運動を利用したインターフェースを持つ食 事支援ロボットシステムを開発した。 5 )超音波モータは圧電素子 の超音波振動による摩擦力を動力とするモータであり, DC モー タをはじめとする電磁力モータとは異なり電磁両立性 (EMC: electromagnetic compatibility)を持つ. 従って, ペースメーカ を装着している障害者が接近しても安全である. また, 超音波モ 一夕は一般的に動作音が静穏であり, 駆動時の不快感が少ない ことも特徵の一つである. ロボットのインターフェースには眼球操 作を採用したが(アイ・インターフェース), これはジョイスティック やタッチセンサとは異なり, 視力が損失していなければ使用可能 である. 更に, 目で見て操作することは, 目で見て手で操作する ことに比べて直観的で分かりやすい. 従って, 高齢な上肢不自 由者でも比較的操作しやすい. 食物を口まで運ぶ機構には直交 座標系を採用したが, これは従来型のロボットアームでは掴めな い崩れやすいものや汁気の多いものの摂食支援を行うことも目 的としているからである. また, 機構としてもアームに比べて部品 点数が少なく抑えられることから, より安価にロボットを製作できる 上に制御しやすいといらメリッ恼ある. 各ロボットのアクチュエータ 及びインターフェースを Table 1 に示す. 
Table 1 Actuators and interfaces of meal-assistance robots

\begin{tabular}{|l|l|l|}
\hline & Actuators & Interfaces \\
\hline iARM & DC motors & Joy stick \\
\hline HANDY1 & DC motors & Touch panel \\
\hline My Spoon & Stepping motors & Joy stick \\
\hline $\begin{array}{l}\text { Proposed } \\
\text { System }\end{array}$ & $\begin{array}{l}\text { Ultrasonic } \\
\text { motors }\end{array}$ & Eye-interface \\
\hline
\end{tabular}

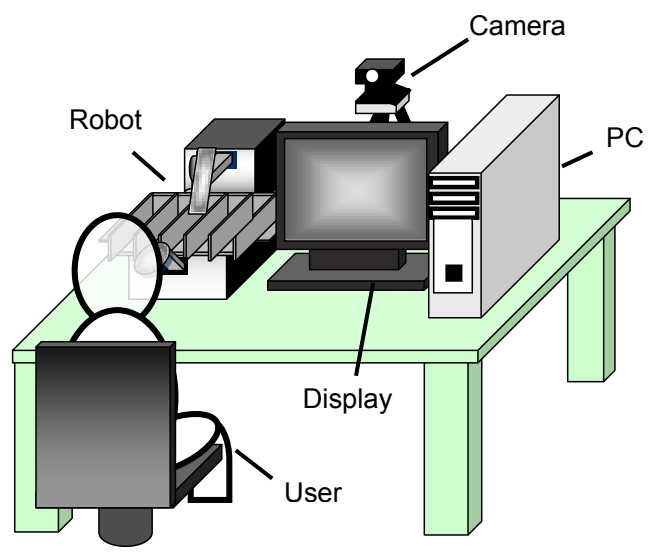

Fig.1 Proposed meal-assistance robot system

本稿では, 著者らが開発した上肢障害者用食事支援ロボット システム(Fig.1)について解説する.

\section{2. 超音波モ一タを用いた直交座標系の食事支援ロボット}

本章では，開発した食事支援ロボットシステムのうち，実際に 食事支援を行うロボット (Fig.2)の機構について説明する. ロボッ トは, 食べ物を置く血の部分, 食べ物を押し出寸部分 (押出し 棒), 食べ物を口元まで運ぶ部分 (スプーン)で構成されている. 皿の部分は 5 つに仕切られており, 各スペースに 1 口大の食物 を 2 個置くことができる. 押出し棒は前後に駆動する部分(プッシ ヤー)と上下に駆動する部分(シャッター)の 2 つで構成されてお り，食物の手前まで移動するとシャッターが下がり，食物をスプー ン上に押し出す. その後, スプーンが使用者の口元まで伸長し, 食事を支援する. 各部にはラック\&ピニオン (Fig.3)を用いてお り, モータのギアに取り付けたピニオンに回転力を加えることによ って, ラックが水平方向に動き, 直進運動する. 本提案ロボットの 駆動部分はこの直進運動のみで構成されており, 高精度かつ高 出力な動作が容易である. また, 単純な平行移動しか行わない ため, 食事支援の際の振動を極力抑えることができる.

本提案ロボットのアクチュエータには回転型の超音波モータ (新生工業製: USR30-S3)を用いた. その構成を Fig.4 に示す. 当該製品は, $50 \mathrm{kHz}$ 付近の 2 相の交流を印加することで圧電セ ラミックと弾性体から構成されるステータを振動させ，進行波を発 生させることで圧着されたロータを摩擦力で駆動させる仕組みで

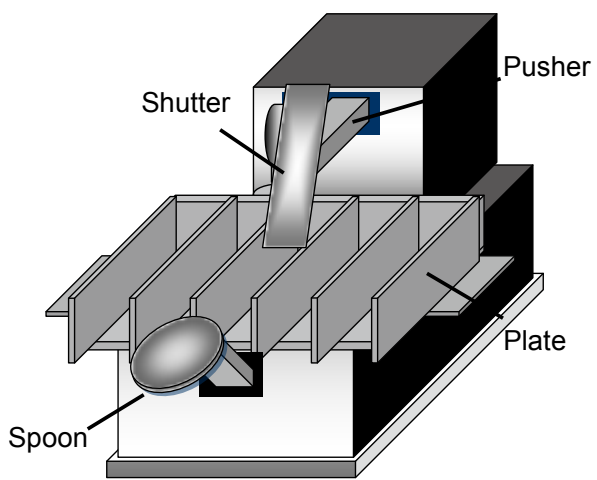

Fig.2 Structure of proposed robot

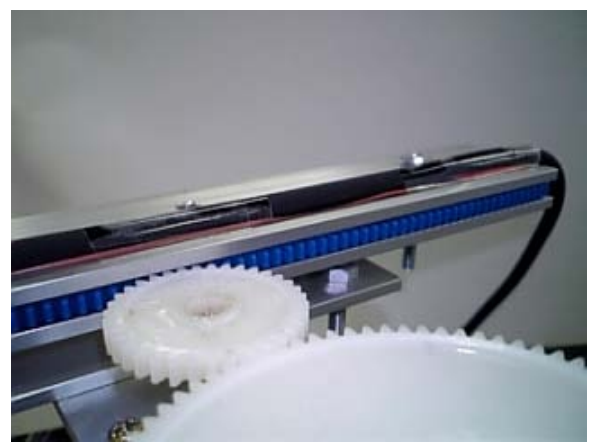

Fig.3 Rack and pinion

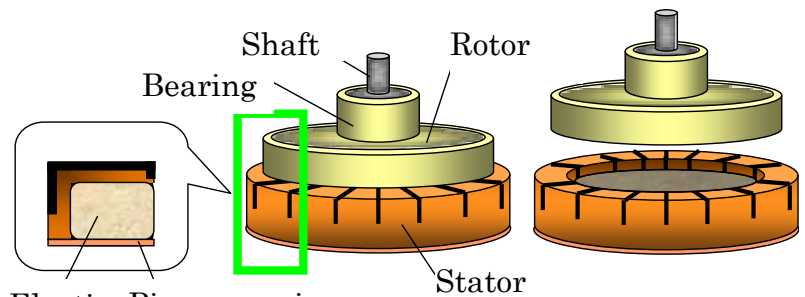

Elastic Piezoceramic

body

Fig.4 Structure of ultrasonic motor

ある. 超音波モ一タは一般的な DC モータと比較して次のような 特徵がある:

1. 低速時に高トルクを発生する.

2. 無通電時に保持卜ルクを有する.

3. 応答が速い.

4. 電磁両立性に優れる.

5. 静肃性に優れる.

これらの特徵から, 本提案ロボットは電磁ブレーキを搭載せず とも制御が可能であり，ペースメーカ装着者でも接近可能であり， また食事支援動作中の騒音も少なくて済む. 以上のことから, 超 音波モータは食事支援ロボットに適していると言える. 
3. アイ・インターフェース

上肢障害者が自らの意思で食事支援ロボットを操作するため には，上肢を用いないインターフェースを採用する必要がある. それに加え, 重度の上肢障害者は下肢をはじめとする他の部位 にもハンディキャップを背負っている場合が多い. そこで我々は, 眼球動作を用いた 2 種類のインターフェース(アイ・インターフェ ース)を構築した.一つは, Fig.5(a)に示す虹彩(Iris)の挙動を 用いた視線検知型アイ・インターフェースであり, いま一つは, 眼 瞼(Eyelid)の開閉動作を用いた瞬目検知型アイ・インターフェー スである. 以下, 詳細を述べる.

\section{1 視線検知型アイ・インターフェース}

まず, 虹彩領域を検出するために, Fig.5(b)に示すテンプレー 卜画像を用意する. サイズは $16 \times 16$ pixel で 8bit のグレースケー ルである.濃淡值は, 虹彩を 0 , 強膜(Sclera)を 128 , 上瞼 (Upper eyelid)および下瞼(Lower eyelid)を 255 とした.

このテンプレート画像を, 進化的動画像処理 6)を用いて探索 対象である 320×240pixel のグレースケール画像(ターゲット画 像) とマッチングさせる. 進化的動画像処理とは, Fig.6 に示す通 り遺伝的アルゴリズム(GA：Genetic Algorism)を用いた動画処 理である. 基本的には静止画を連続的にテンプレートマッチング する手法だが, 高精度を保ちつつ処理時間を短くする工夫がな されている. 静止画における GA を用いた基本的なテンプレート マッチング法をそのまま動画に適用すると, 静止画一枚毎に初 期值を乱数で与えることになる. それに対し, 進化的動画像処理 では 2 フレーム目からは前のフレームで得られた遺伝子情報を 継承している.これは, 1 フレーム程度であれば虹彩の情報に大 幅な変動がないことを利用したものであり, フレーム毎に乱数を 用いるより高速に最適解に収束することが期待できる.

本研究で用いた染色体モデルは, 虹彩の中心座標 $\left(t_{x}, t_{y}\right)$, テンプレート画像に対する拡大縮小倍率 $m$, 及び回転角度 angle の情報をそれぞれ 8bit 持つものとして構成されている (Fig.7).

以上の準備のもと逐次テンプレートマッチングを行い, 虹彩の 位置座標から移動量を計算し, 移動量が $\mathrm{x}$ 軸と $\mathrm{y}$ 軸でそれぞれ 5pixel 以下であれば注視と判定する.この処理を次の注視時ま で繰り返し, その変位を視線の移動距離として算出する.

\section{2 瞬目検知型アイ・インターフェース}

まず, 時刻 $k-1$ 及び時刻 $k$ における 2 枚の画像 (Fig.8)に対 する差分画像 (Fig.9)を求め, 2 值化処理および杂隹音除去を行 う. その後に, 白色部分の輪郭を抽出する. 得られた輪郭が $2 つ$ で, それらについて, 重複がない, 同程度で一定の面積である, 横軸にほぼ平行である, と言った眼瞼として満たすべき条件が整 っている場合に眼瞼の開閉，すなわち瞬目を検知できたと判定 する. 本研究では, これらの処理は OpenCV7)で行っている.

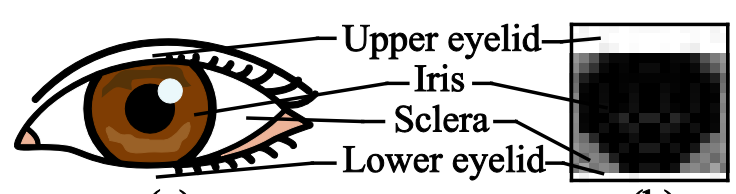

(a)

(b)

Fig.5 Model of eye and template figure: a) Model of eye, b) Template figure of eye

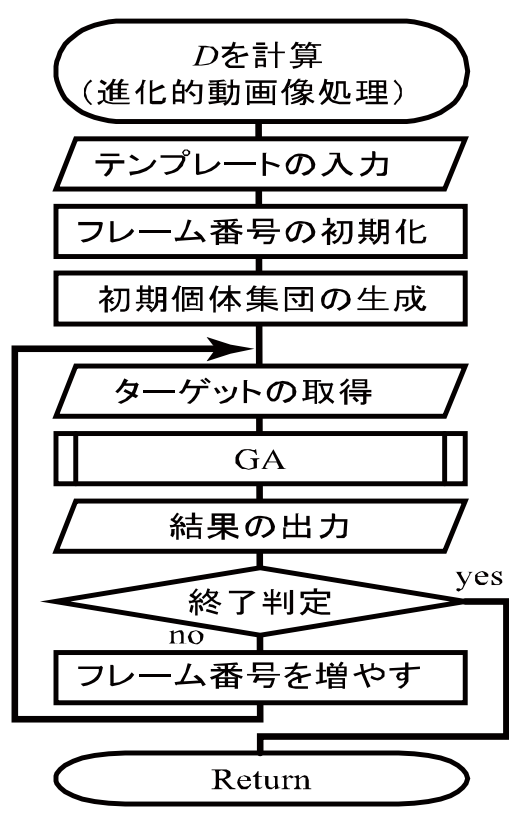

(a)

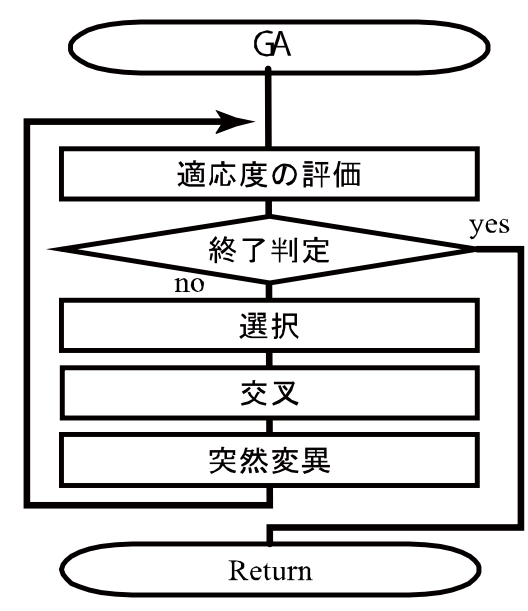

(b)

Fig.6 Evolutionary video processing a) Main loop, b) Sub loop

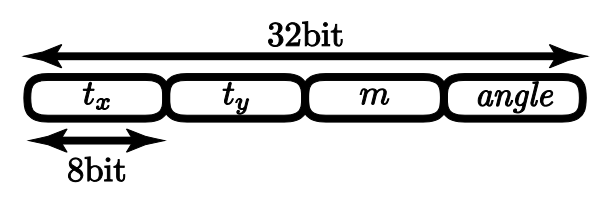

Fig.7 Model of chromosome 


\section{4. 食事支援ロボットシステム}

著者らが開発した食事支援ロボットを Fig.10 に, 操作画面を Fig.12 及び Fig.14 に示す. 本提案ロボットシステムは, 次の手 順で動作する.

1. システムが使用者の顔を逐次検出する.

2. 使用者が食べたい皿番号の選択を行う.

3. 選択した皿の食物をロボットがロ元へと運ぶ.

4. 皿の選択に戻る, 又は食事を終了する.

1.ではまず, カメラ画像から使用者の顔を高速検出し, 次に適 切な画像を撮影するようにカメラを自動調整する(Fig.11). 顔の 検出には Adaboost 学習アルゴリズムを採用し, カメラの制御に はパン・チルト・ズームを用いた.これらの手法により, 顔と画面の 中心を一致させ, かつ顔のサイズが画面の 0.8 倍となるようにカメ ラを制御することが可能となる.

2.におけるロボットの操作方法は, 前述した 2 つのインターフェ 一スによって若干の違いがある. 視線検知型アイ・インターフェー スでは, まず Fig.12(a)の中央にあるカーソルを見て視線のデー タを初期化し, 次にカーソルを移動させたい方向へ目を動かす (Fig.13). 1 秒注視するとカーソルが目的の区画へ移動し (Fig.12(b)), その後 4 秒閒注視を続けると区画が決定される. 一方, 瞬目検知型アイ・インターフェースでは, Fig.14(a)の画面 においてカーソルが一定の時間間隔で動いており, 目標とする 区画にカーソルが来たときに眼瞼開閉を 2 度行うと, 確認画面 (Fig.14(b))に切り替わる. ここで更に眼瞼開閉を行えば区画の 決定, しなければ一定時間後に再び Fig.14(a)の画面に戻る仕 組みである。

3.において, ロボットは次の手順で動作する.まず, 選択した 皿をスプーンの正面に移動させ，次にシャッターで食物をスプー ンの上に押し出し, スプーンを伸長させ食物を口元まで運ぶ. 各 皿は 2 口目まで食べられるようになっている(Fig.10(b)). 従っ て, 配膳の際には 1 ロサイズに加工し, 各仕切りの手前に食心゙ 物を配置する必要がある. なお, 1 口目か 2 口目かをロボットに記 憶させることで, 食物を押し出す際のシャッターの初期位置を変 更している.

4.において, 食事を終了することを選択すれば，皿に食物が 残っていても中断する.

\section{5. 提案システムの特徵}

本提案システムの大きな特徵の一つは, 直交座標系の採用に より従来は支援困難であるとされてきた食物の摂食支援が可能と なる点である. 著者らは, 白米, 白桃, 豆腐, ナポリタンについて 実機実験を行って, その有用性を確かめている. 白米は日本人 の主食であるため最もニーズが高いと考えられるが, 掴む動作で は米粒が分離し易く, 支援中に落下寸る恐れがある. 本提案ロボ

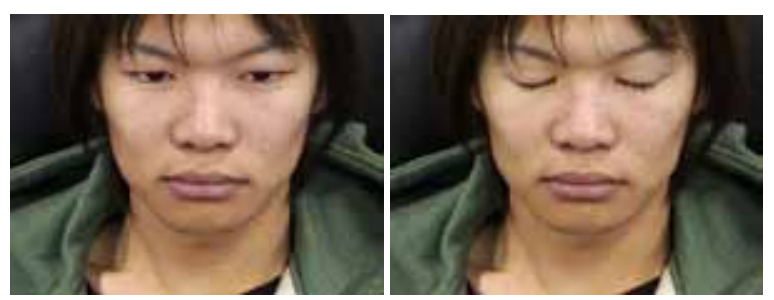

Fig.8 Images of face:

a) Image of time $k^{-1}$, b) Image of time $k$

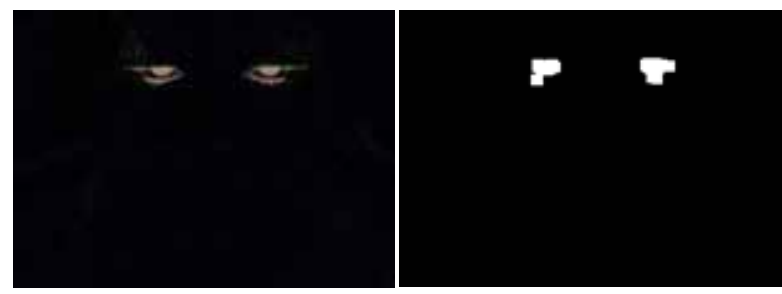

Fig.9 Computer-processed image:

a) Difference image, b) Detection image of blinking

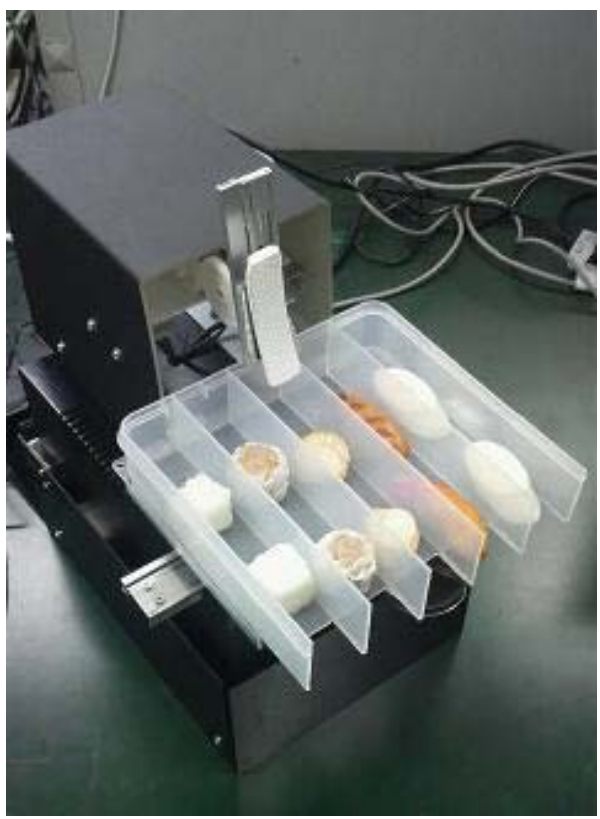

(a)

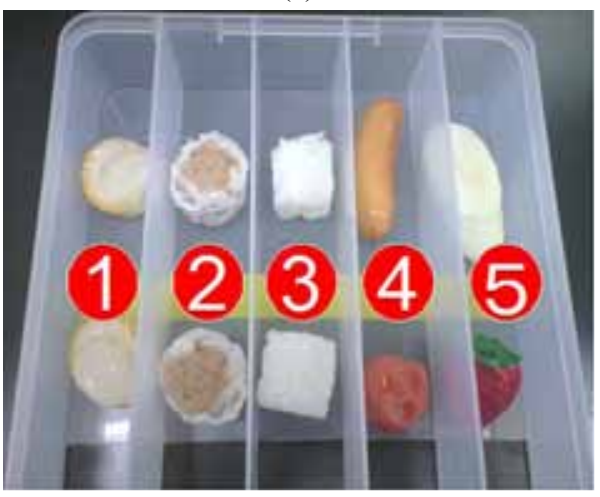

(b)

Fig.10 a) Meal-assistance robot, b) Numbers of parts of plate 
ットでは, 俵状に固めて皿にセットすれば, シャッターに米粒が付 着することもなく無事に支援できることを確認した. 白桃は果汁が 多いため滑りやく, 掴んだり掬ったりするのは難しい, 一方, 本 提案システムは押し出す機構なので, 食物が滑ることは八ンディ キャップとはならない. 豆腐は滑りやすい上に崩れやすいといら 特徴を持っている. 掴んで口元まで運ぶのは健常者でも失敗し やすい食物であるが, 本提案システムのシヤッターはゆっくり動く ので, 形状をほぼ保ったまま食することが可能である. 最後のナ ポリタンは, 一般的にロボットによる摂食支援の困難な麵類であ る. 掴む・掬うといった動作はもちろんのこと, 押し出す機構であ っても成功するとは限らない. 実際, 本提案システムで行った 20 回の試験のうち失敗が 2 回あった. このうち 1 回はシャッターと血 との間に食物が挟まってしまい, もう 1 回においてはスプーンの 伸長中に麺が落下してしまった. しかし, 残りの 18 回は成功して おり，成功率から言えば実用性は有していると考えられる.

本提案システムのいま一つの特徴は, アイ・インターフェース の採用にある. 眼球の残存している上肢障害者は多い為, 体の 一部を接触させて操作するインターフェースと比べて使用対象 者が幅広い. また, 視線検知型と瞬目検知型の 2 種類のインタ ーフェースを開発した主な理由は, 操作感の違いを考慮したもの である. 視線検知型では進化的動画像処理を用いて虹彩の移 動を検知して画面の注視を選択の決定と判断しているが, 幾つ か技術的な問題がある. 一つは眼球が常に微小振動しているこ と(固視微動 8)) による誤検知であり，いま一つは瞬目によって虹 彩が検知できずにカーソルが初期位置に戻ってしまうことであ る.これらの問題を解決する為に, インターフェース操作画面に おける各区画の端に赤い四角の枠を描画し(Fig.15)，更に注視 を行う 4 秒間をカウントダウン表示する方式にした. 固視微動は 注視する目標が小さい方が少ない傾向にあり，8)瞬目は意識が 目標に集中している際に抑制される傾向にある為, 9)この方法は 有効である.この手法については既に実験を行い, 有用性を示 した. ${ }^{10)}$ 一方の瞬目検知型は, 眼瞼の開閉さえ検知できれば良 いため, 視線検知型に比べて実装は容易である. しかし, 自発的 な瞬目 (随意性瞬目)だけを利用寸る為, 無意識に起こる瞬目 (周期性瞬目) や受光による瞬目 (反射性瞬目)などの誤検知を 防ぐ必要がある. この問題は, 検知すべき自発的な瞬目をゆっく りしたものに限定することでほぼ解決する. また, 瞬目検知型で は視線の移動を検知しないのでカーソルを周期的に移動させる 必要があり, 使用者によってはストレスとなりかねない. 注視の方 が良いか瞬目の方が良いか，使用者の好みに合わせて設定を 容易に変更できるのが本提案システムの利点の一つである.

また, 駆動部に超音波モータを採用したことにより, 電磁両立 性が確保できた.このことは, ペースメーカ装着者が接近しても 問題がないことを意味する. 更に, 前述の通り超音波モー夕は応 答が速く, 無通電時に十分な保持卜ルクを有する.このことは, 予 期しない誤作動が発生した際に緊急停止させるのが容易であ り, 停電時には機構全体に自動でロックが掛かった状態になるこ とが見込まれる.このような安全面においても本提案システムは
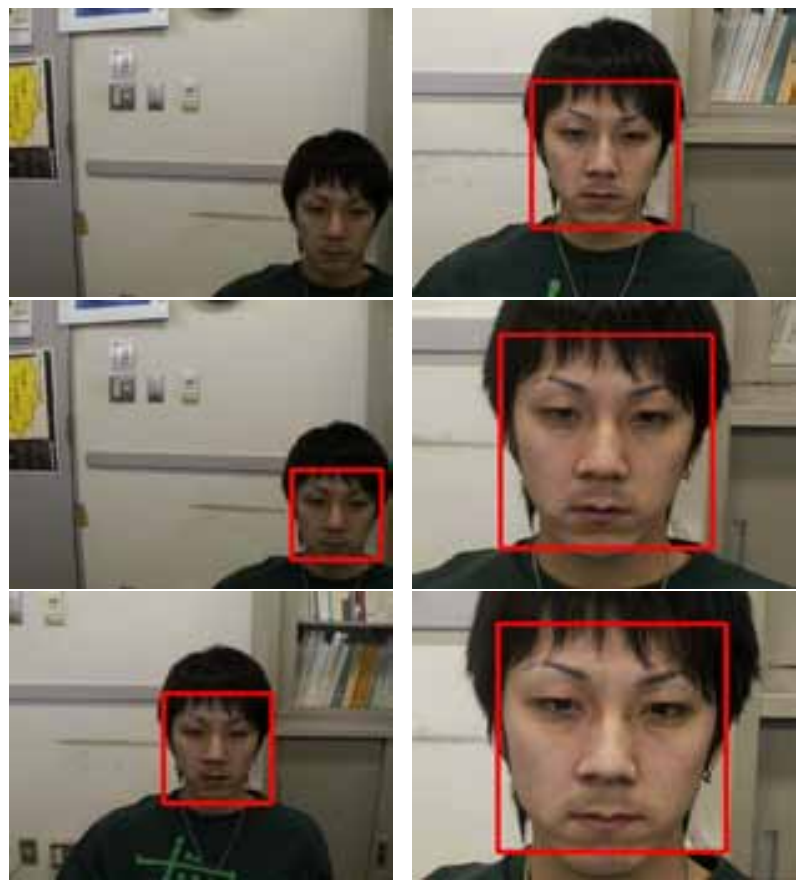

Fig.11 Detection of face

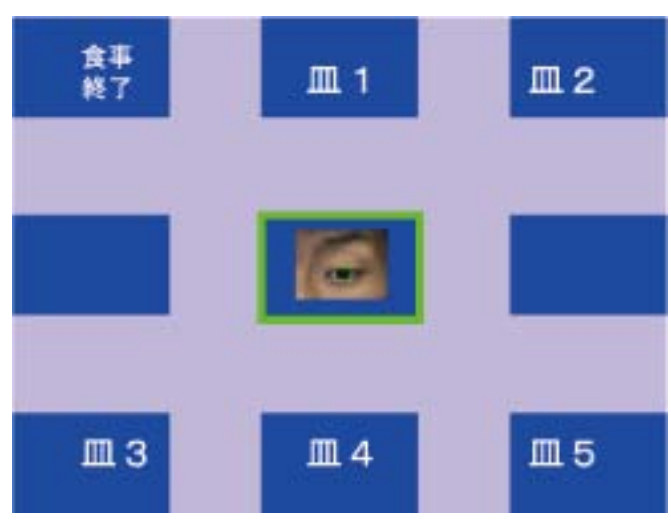

(a)

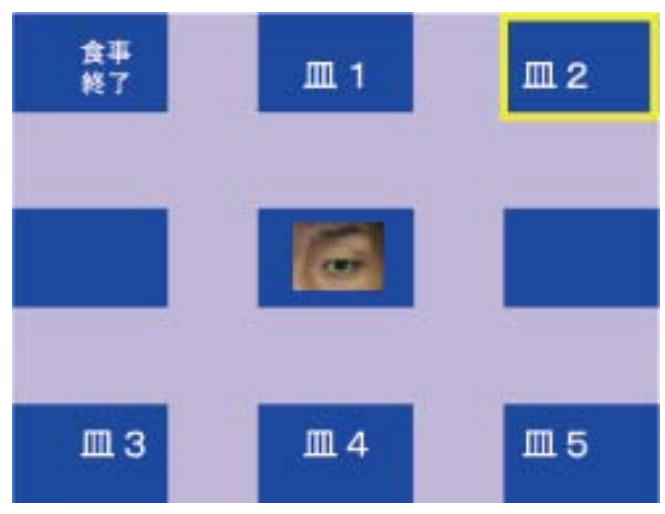

(b)

Fig.12 Operation screen of iris-type eye-interface: a) Initial state, b) State after selection 
優位にある. 更に, 高価な部品をほとんど使用しておらず, 部品 点数も多くはない. インターフェースとして用いるパーソナルコン ピュータも市販品で十分であり, カメラも安価な USB カメラでよ い. 従って, 既製品に比べてトータルコストを下げられることが期 待できる.

本提案システムの特徵をまとめると, 次のようになる.

•使用対象者が幅広い(アイ・インターフェース)

・安全性が高い(超音波モータ)

•支援可能な食物が多い(直交座標系の機構)

-比較的安価

\section{6. おわりに}

今後の日本では少子高齢化により医療福祉分野に要求される 技術もハイレベルなものになっていくことが見込まれる. 本稿で は，当該分野の中でもとりわけニーズが高まると予想される食事 支援のシステムを扱い, 著者らが開発したロボットシステムを紹介 した. 実用化に向けて細かい改良を重初ていく必要はあるもの の, 大まかな構成は完了したと考えている.

\section{参考文献}

1）厚生労働社会·援護局障害保険福祉部, 平成 18 年身体 障害児·者実態調査結果. 厚生統計協会 2008; 4.

2）テクノッール ロボット事業部 アイアー ム, http://www.ttools.co.jp/robot/arm.html, 2010/03/19 アクセス.

3) M. Topping, An Overview of the Development of Handy1. a Rehabilitation Robot of Intelligent and Robotic Systems 2002; 34: 253-263.

4）石井純夫，食事支援ロボット「マイスプーン」，日本ロボット 学会誌 2003; 21(4): 44-47.

5) Y. Kodani, K. Tanaka, Y. Wakasa, T. Akashi, and M. Oka, Meal Assistance Robot with Ultrasonic Motors. Proc. of 2007 International Conference on Mechatronics and Information Technology 2007.

6) T. Akashi, M. Fukumi, and N. Akamatsu, Real-Time Genetic Lips Region, Detection and Tracking in Natural Video Scenes. Proc. of IEEE Conference on Cybernetics and Intelligent Systems 2004.

7）奈良先端科学技術大学院大学 OpenCV プログラミングブ ック製作チーム, OpenCV プログラミングブック.第 1 版. 東京:毎日コミュニケーションズ, 2007.

8）境野, 鉄谷, 岸野, 最大エントロピー法と高次モーメント 特徵量に基づく眼球運動パターンの時系列解析. 電子 情報通信学会論文誌 1993; J76-A(8): 1024-1041.

9）小濱, 新開, 臼井, マイクロサッカードの解析に基づく視 覚的注意の定量的測定の試み。映像情報メディア学会 誌 1998; 52(4): 571-576.

10）小松, 田中, 若佐, 西村, 岡, 上肢障害者のための食事 支援口ボット. 第 7 回生活支援工学系学会連合大会 2009; 3D1-3(018).

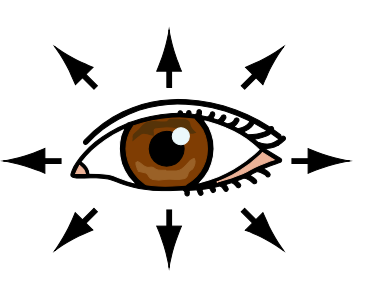

(a)

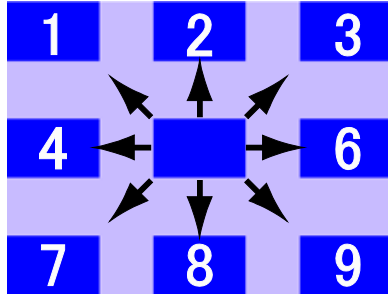

(b)
Fig.13 Relation of movement of iris and operation screen: a) Directions of movement of iris, b) Operation screen

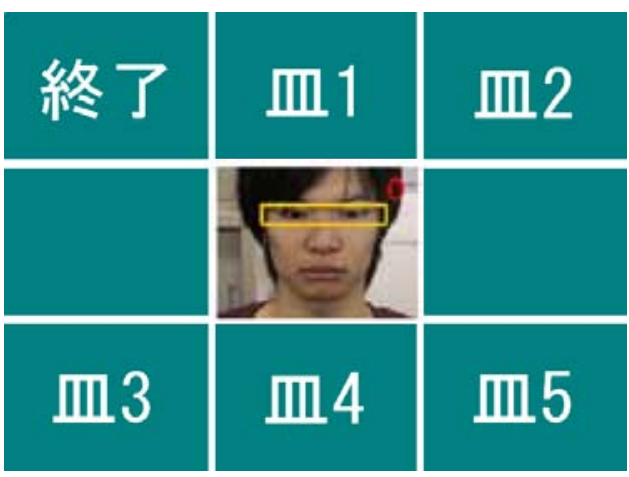

(a)

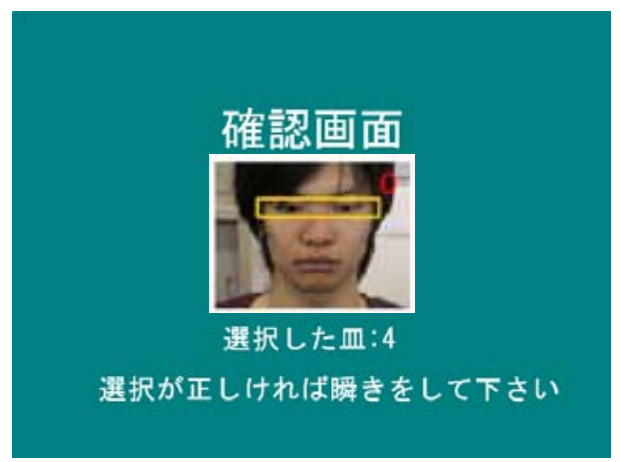

(b)

Fig.14 Operation screen of blinking-type eye-interface: a) Initial state, b) State after selection

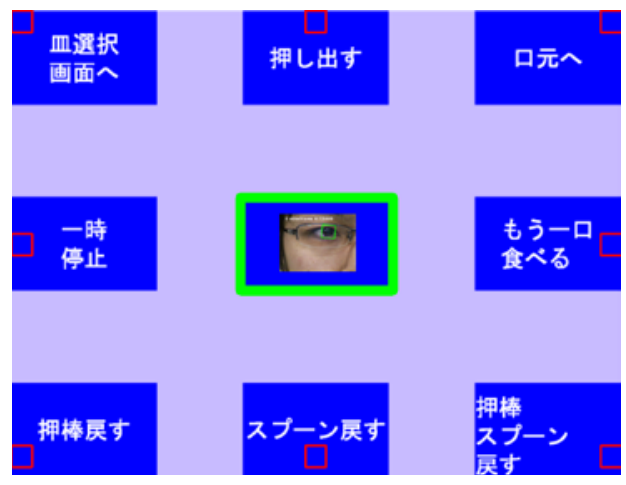

Fig.15 Developed operation screen of iris-type eye-interface 